\title{
Does Economic Growth in Nepal Cause Electricity Consumption
}

\author{
Kamal Raj Dhungel
}

\begin{abstract}
This article examines the causal relationship between the per capita electricity consumption and the per capita real GDP (natural logarithm) during the period 1980-2006 in Nepal using co-integration and vector error correction model. According to the findings, there is a unidirectional causality from per capita real GDP to per capita electricity consumption. Results show that per capita electricity consumption does not cause per capita real GDP. There is an important policy implication of the findings. It is important because it has significant implications from the point of view of energy conservation, Green House Gas emission reduction and economic development. Energy conservation if the government or the power utility industry approves the appropriate national policy for entering into the practical action will enhance economic development in a sustainable basis.
\end{abstract}

Key words: Co-integration, unit-root, causality, energy conservation, electricity consumption, economic growth, Nepal

\section{Background}

There was no worry on the problem of pollution as long 1 as the world remained sparsely populated in which no permanent cities and towns existed. With the pace of development and modernization along with the high growth rate of population, more cities and towns have come into existence in which the material well being of the people has increased tremendously. Since then, the production and consumption of goods and services has registered a high growth rate. Nature has caused a severe constraint on the continuing process of achieving high growth rate in the world's economy as nature itself is a major component on further progress. The 19th century economist J.S. Mill emphasized the idea that we need to protect Nature from unregulated growth if we are to preserve human welfare before diminishing returns begin to set in. In a similar fashion, Malthus stressed the limitation of carrying capacity of the environment when he analysed the relationship between food production and population growth.

A prime objective of underdeveloped countries is to reduce poverty. This objective is not meaningful unless it is tied to sustainable development to achieve desired level of economic growth. As the livelihood of poor depends mainly on the natural resources, depletion in an unplanned manner will hit the livelihood of the poor the hardest. To provide a decent living for the poor, development activities should be guided by the principles of sustainable development. This implies that any plan that focuses on the development potential of a country should focus to achieve the dual goal of reducing poverty and achieving sustainable development. The term Sustainable Development as defined by the Brundtland Commission (1987) means development that "meets the needs of the present without compromising the ability of future generations to meet their own needs." It follows that economic development should be maintained within the acceptable levels of global resources and environment pollution.

Today the world is experiencing an uncontrolled use of fossil fuels that emit Green House Gases (GHG) into the atmosphere, which leads to global warming and stimulates climate change. There are, however, very few alternatives for fossil fuels, and those that exist are not affordable to everyone. Economic and social development depend primarily on the use of energy. This implies that there is a strong and positive association between the growth rate of an economy and growing rate of energy consumption. Excessive use of energy, particularly fossil fuels, for accelerating the economic growth rate of developing countries results in the excessive emission of carbon dioxide $\left(\mathrm{CO}_{2}\right)$ into the atmosphere. Furthermore, the energy requirement of developing countries is not only fulfilled by fossil fuel, but also by biomass which is another major source of air pollutants. The excessive dependence on biomass depletes natural resources, particularly forests. Hence, desertification arises as a problem, and is the most probable consequence of endangerment of the livelihoods of living creatures on earth.

Can development of alternative energy be a solution to reduce GHG emissions? Certainly it would, as today's technological advancements can develop those alternatives that are environmentally friendly and harmless to the ecology.

Nepal has two possible options to reduce the use of fossil and biomass fuel: (1) the development of immense water resources for generating electricity and (2) the use of animal dung for generating biogas. These options, if developed adequately, might be helpful in reducing GHG emissions. This article particularly is devoted to analyzing the role of electricity in the path of economic development and examining the causal relationship between electricity consumption and economic growth in Nepalese economy.

\section{A Brief Survey of the Literature}

A number of studies have been conducted to investigate the casual relationships between energy consumption and economic growth. Kraft and Kraft (1978) used Sims (1972) methodology to assess causality between energy consumption and economic growth over the period 19471974. Their work explicitly proved that the causality was running from GNP to energy consumption in the US 
economy. Dhungel (2008) has found a unidirectional running from coal, oil and commercial energy to per capita real GDP and a unidirectional causality from per capita real GDP to per capita electricity consumption. Aqueel and Butt (2001) studied the causal relationship between energy consumption and economic growth. To investigate the causal relationship among the stated variables, they prefer to use the integration and Granger tests. They found unidirectional causality running from economic growth to petroleum consumption and causality running from economic growth to gas consumption. On the contrary, their investigation found unidirectional causality running from electricity consumption to economic growth. Cheng and Lai (1997) investigated the causality runs from GDP to energy consumption in the case of Taiwan. They use a co-integration and error correction model to investigate the causality among the chosen variables. Mozumdar and Marathe have applied vector error correction model (VECM) to explore the dynamic Granger causality. They found that per capita gross domestic product Granger causes per capita energy consumption. Mashih and Mashih (1996) consider six Asian economies to examine the temporal causality between energy consumption and income. They have applied vector error correction model (VECM). Their finding shows that energy consumption is causing income in India, income is causing energy consumption in Indonesia, bi-directional causality exists in Pakistan. However, they use an ordinary vector autoregressive (VAR) model for the rest three countries (Malaysia, Singapore and the Philippines). Their investigation failed to find any causality between energy consumption and income. Soytas and Sari (2002) in their study of examining causality, found mix results. They found bidirectional causality in Argentina. By comparison, their study also investigated the causality running from GDP to energy consumption in Italy and Korea; in contrast they also found the causality running from energy consumption to GDP in Turkey, France, Germany and Japan.

The study by Yang (2000), using updated data for 1954-1997 for Taiwan, investigated the casual relationship between GDP and the aggregate categories of energy consumption, including coal, natural gas and electricity. He found bidirectional causality between total energy consumption and GDP. Pachauri (1977) found that there was a strong correlation between economic development and energy consumption in the case of India. Stern (2000), in a study for the US macro economy, found in a multivariate dynamic analysis that energy Granger causes GDP and that energy is significant in explaining the latter. $\mathrm{He}$ also found that there co-integration in a relationship including GDP, capital, labour and energy. Ghali and El-Sakka (2004) have conducted a study on the causality between energy consumption and economic growth using Johansen's methodology in Canada. They found that the short run dynamics of variables indicate that Granger's causality is running in two directions between output growth and energy use. Dhungel (2005) used co-integration to determine electricity demand in Nepal. The estimated income elasticity and price elasticity of electricity showed that there is a proportional change in the demand for electricity associated with changes in income and price.

\section{Energy Sector in Nepal}

Nepal's energy sector infrastructure is very small, inefficient, unreliable and poorly managed. The per capita energy consumption is very low, approximately 15 GJ per annum (Dhungel 2003). The energy consumption of Nepal has been dominated by traditional sources. The share of traditional energy to total was $85.8 \%$ in the fiscal year 2005/o6 (Table 1). The annual growth rate of traditional energy consumption was $1.3 \%$ during the period of 2000/01-2005/06. In the same period of time; the commercial energy consumption was increased by $2.49 \%$ per annum. The share of commercial energy represents $14.2 \%$ out of which share of coal, oil and electricity in total commercial energy was $22.7,58.5$ and $18.8 \%$ respectively during the same period of time. Nepal has small reserves of coal. The coal consumption has been increasing over time. There is, however, no proven source of petroleum products but an immense hydropower potentiality in Nepal.

Electricity is one of major sources of power for the nation's most economic activities. Nepal's installed electric generation capacity (hydro and thermal) is 688.24 MW (Nepal Hydropower Database, 2009). Only 40\% of population has access to electricity with a very low per

\begin{tabular}{|c|c|c|c|c|c|c|c|c|c|}
\hline \multirow[b]{2}{*}{ Year } & \multirow[b]{2}{*}{ Traditional } & \multicolumn{4}{|c|}{ Commercial } & \multirow{2}{*}{ Renewable } & \multirow{2}{*}{ Total } & \multirow{2}{*}{$\begin{array}{c}\text { Traditional } \\
\text { share } \%\end{array}$} & \multirow{2}{*}{$\begin{array}{c}\text { Commercia } \\
\text { share \% }\end{array}$} \\
\hline & & Coal & Oil & Electricity & Total & & & & \\
\hline $2000 / 01$ & 6824 & $\begin{array}{c}174 \\
(17.1)\end{array}$ & $\begin{array}{c}734 \\
(72.2)\end{array}$ & $\begin{array}{c}108 \\
(10.6)\end{array}$ & 1016 & 29 & 7869 & 86.7 & 13.3 \\
\hline $2001 / 02$ & 7066 & $\begin{array}{c}152 \\
(14.8)\end{array}$ & $\begin{array}{c}758 \\
(73.7)\end{array}$ & $\begin{array}{c}119 \\
(11.6)\end{array}$ & 1029 & 33 & 8128 & 86.9 & 13.1 \\
\hline $2002 / 03$ & 7240 & $\begin{array}{c}134 \\
(13.2)\end{array}$ & $\begin{array}{c}753 \\
(74.2)\end{array}$ & $\begin{array}{c}128 \\
(12.6)\end{array}$ & 1015 & 39 & 8294 & 87.3 & 12.7 \\
\hline $2003 / 04$ & 7397 & $\begin{array}{c}171 \\
(16.1)\end{array}$ & $\begin{array}{c}747 \\
(70.5)\end{array}$ & $\begin{array}{c}141 \\
(13.3)\end{array}$ & 1059 & 45 & 8501 & 87.0 & 13.0 \\
\hline $2004 / 05$ & 7558 & $\begin{array}{c}152 \\
(15.0)\end{array}$ & $\begin{array}{c}705 \\
(69.5)\end{array}$ & $\begin{array}{c}157 \\
(15.5)\end{array}$ & 1014 & 45 & 8617 & 87.7 & 12.3 \\
\hline $2005 / 06$ & 7278 & $\begin{array}{c}261 \\
(22.7)\end{array}$ & $\begin{array}{c}672 \\
(58.5)\end{array}$ & $\begin{array}{c}216 \\
(18.8)\end{array}$ & 1149 & 52 & 8479 & 85.8 & 14.2 \\
\hline GR & 1.30 & 8.45 & -1.75 & 14.87 & 2.49 & 12.39 & 1.50 & -0.20 & 1.30 \\
\hline
\end{tabular}

Table 1. Energy Consumption Pattern in Nepal (in Thousand Ton of Oil Equivalent) Note: GR = Growth Rate. A figure in parenthesis represents percentage of total commercial energy. Source: Economic Survey, Ministry of Finance, Government of Nepal, 2007. 
capita availability of $71 \mathrm{kWh}$ per annum (Tenth Plan, nationmaster.com). The per capita electricity consumption of Nepal is the lowest even among the South Asia Association for Regional Cooperation (SAARC) member countries (Table 2).

Table 2. Per Capita Electricity Consumption in 2006 (kWh)

\begin{tabular}{|c|c|c|}
\hline Country & $\begin{array}{c}\text { Electricity Consumption } \\
\text { (kWh/annum) }\end{array}$ & $\begin{array}{c}\text { Rank out of 218 } \\
\text { countries }\end{array}$ \\
\hline Norway & 24011 & 2 \\
\hline USA $^{*}$ & 12924 & 9 \\
\hline Singapore & 8176 & 19 \\
\hline China & 2179 & 91 \\
\hline India & 466 & 160 \\
\hline Pakistan & 430 & 164 \\
\hline Sri Lanka & 348 & 165 \\
\hline Bhutan & 227 & 170 \\
\hline Nepal & 70.8 & 196 \\
\hline
\end{tabular}

* Data of 2007. Source: http://www.nationmaster.com/index.php

There are various problems facing the development of electricity in Nepal. The electricity sector faces high system losses, delays in completion of new plants, low installed plants efficiency, erratic power supply, frequent load shedding and blackouts, and low efficiency in power plant maintenance. Load shedding, at times, becomes a daily event in Nepal. The electric utility of the country has been characterized by the low management efficiency and low generating capacity that, in turn, has led to frequent load shedding. Power outages result in a loss of industrial output and reduce GDP growth. A major obstacle in efficiently delivering power is caused by the low generating capacity and an inefficient distribution system. The total transmission and distribution losses is $25.15 \%$ (NEA FY 2007/08, A Year in Review); however, many believe that the actual losses is substantially higher than this.

The demand for electricity has grown over the years, ranging from 10 to $12 \%$ per annum over last two decades. Nepal has no well designed plan for electricity generation, if any, the actual implementation lags far behind the planned

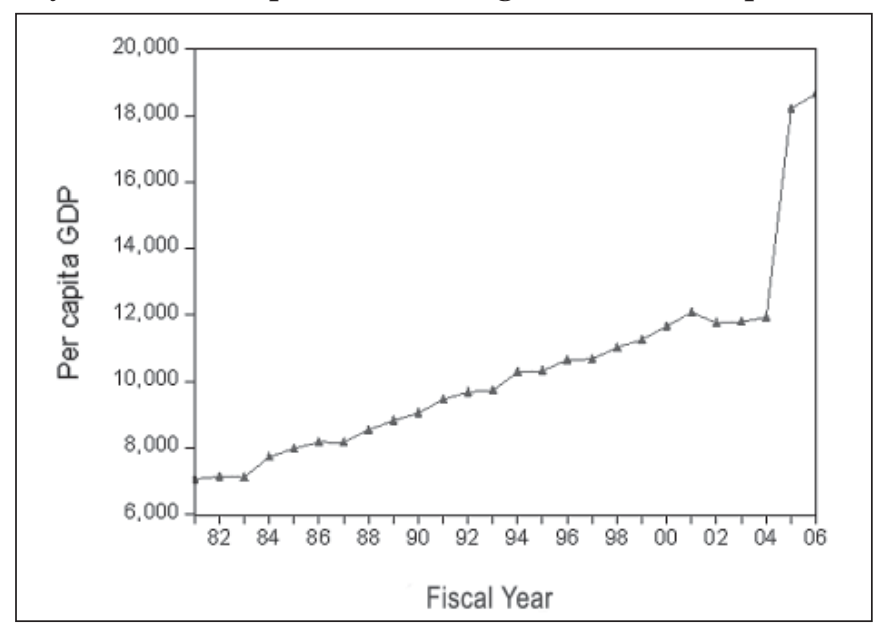

Figure 1. Historical Trend of Per Capita GDP (in Rupees) in Nepal

Source: Data from Economic Survey (1999, 2003, 2007) Ministry of Finance, Government of Nepal targets. Depending on the direction of causality, electricity may turn out to be the most important option to manage the large unmet energy demand in Nepal. If causality runs from per capita electricity consumption to per capita real GDP then conserving electricity may be complex. It would simply mean that as electricity consumption drops, GDP and economic growth will suffer. Hence, in order to determine what the right policy for Nepal should be, one needs to carefully examine the direction of causality between the electricity consumption and GDP. In this article, an attempt has been made to examine the causal relationship between real GDP and electricity consumption for Nepal using co-integrated and Granger causality techniques. Per capita real GDP and per capita electricity consumption in logarithm is used for serving the specified purpose.

\section{Econometric Methodology, Data used and Model and Results Obtained}

\section{The Data and Variables}

The time series data of total commercial energy consumption and real GDP over the period 1980-2006 are used to investigate causal relationship between electricity consumption and economic growth. The necessary data were collected from different sources. The data for electricity consumption were collected from published magazines and office records of the Nepal Electricity Authority (NEA). Similarly the data of GDP have been collected from the different issues of Economic Survey published by the Ministry of Finance of the Government of Nepal.

To estimate the relationship between electricity consumption and economic growth, most of the study uses Gross Domestic Product (GDP) as a measure of economic growth. This article also considers real GDP as a measure of economic growth.

\section{Unit Root Test}

The Augmented Dickey Fuller (ADF) test is preferred as most of the studies have adopted it to examine the unit root

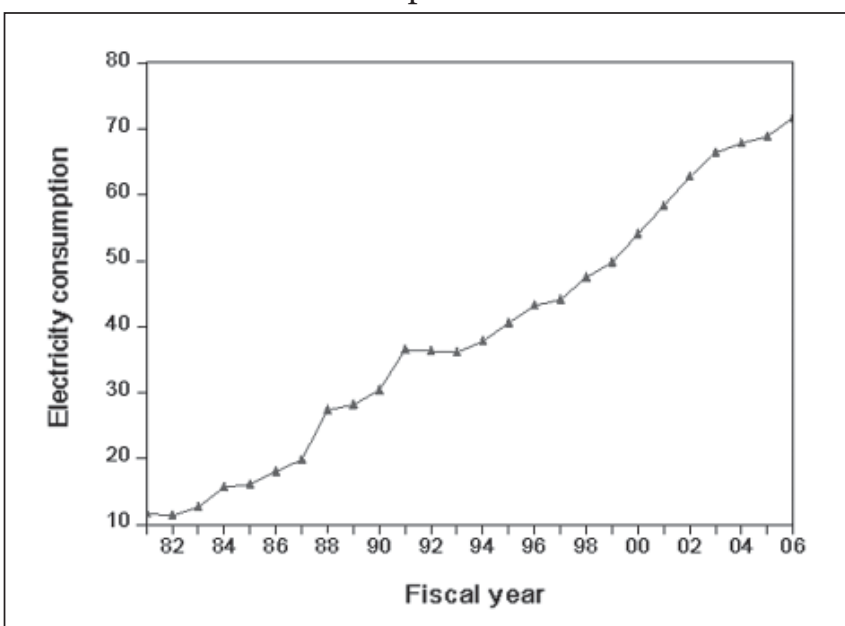

Figure 2. Historical Trend of Per Capita Electricity Consumption of Nepal (in $\mathrm{kWh}$ )

Source: Data from Economic Survey (1999, 2003, 2007), Ministry of Finance, Government of Nepal. 


\begin{tabular}{|c|c|c|c|c|}
\hline Statistics & $\begin{array}{c}\text { Per capita real GDP } \\
\text { in Rupees }\end{array}$ & $\begin{array}{c}\text { Per capita electricity } \\
\text { consumption in kWh }\end{array}$ & Statistics & $\begin{array}{c}\text { Per capita real } \\
\text { GDP in Rupees }\end{array}$ \\
\hline Mean & 10347.27 & 38.9 & Kurtosis & 5.575638 \\
consumption in kWh & Jarque-Bera & 17.93049 \\
\hline Median & 10014.00 & 37.1 & Probability & 0.000128 \\
\hline Maximum & 18657.00 & 71.7 & Sum & 269029.0 \\
\hline Minimum & 7064.000 & 11.3 & Sum Sq. Dev. & $2.06 \mathrm{E}+08$ \\
\hline Std. Dev. & 2869.710 & 19.4 & Observations & 26 \\
\hline Skewness & 1.574588 & 0.2 & 9376.1 & 26 \\
\hline
\end{tabular}

Table 3. Descriptive Statistics for Included Variable

in the series electricity consumption (EC) and real GDP. The $\mathrm{ADF}$ test shows in the level form that the null hypothesis $\mathrm{H}_{\mathrm{o}}: \mathrm{X}_{\mathrm{t}}$ is not $\mathrm{I}(\mathrm{o})$ is rejected for the series EC and GDP at 1,5 and 10 per cent level of significance that the order of integration is not $\mathrm{I}(\mathrm{o})$. It proves that time series data of the series EC and GDP are non-stationary. However in the first difference both series become stationary. The ADF test for the data of first difference supports that both the series EC and GDP of order I(1). The coefficients of the ADF in the level and first difference under the test assumption of constant and linear trend are reported in Table 4.

\begin{tabular}{|c|c|c|c|c|}
\hline \multirow{2}{*}{ Variables } & \multicolumn{2}{|c|}{ Levels } & \multicolumn{2}{c|}{ First Difference } \\
\cline { 2 - 5 } & ADF-values & p-values & ADF-values & p-values \\
\hline InPCEC & $-1.5713(1)$ & 0.4819 & $-5.2837(1)^{*}$ & 0.0003 \\
\hline InPCGDP & $-0.2419(1)$ & 0.9690 & $-4.0207(1)^{*}$ & 0.0057 \\
\hline
\end{tabular}

Table 4. Empirical Results of Unit Root Test

Notes: The numbers inside the brackets are the optimum lag lengths determined using Akaike's information criteria. The $\mathrm{p}$-values are calculated under the hypothesis of nonstationarity.

* Rejection of Null Hypothesis at 1, 5 and 10 per cent level of significance as the Mackinnon values for rejection hypothesis of a unit root test at 1,5 and 10 per cent are $-3.75,-2.99$ and -2.64 respectively.

PCEC = Per Capita Electricity Consumption; PCGDP = Per Capita Gross Domestic Product; ln = Natural Logarithm.

\section{Co-integration Test}

The empirical findings of Johansen co-integration tests (Table 5) reveal that both tests indicate the existence of a consistently co-integrating vector or long run equilibrium relation among variables during the sample period of 1980-2006. While estimating the values of the test no deterministic trend was assumed. The lag interval in first differences is 1 which is chosen according to the Akaike's information criteria. Trace and Maximum eigenvalue test indicate that there is one co-integrating equation at the 5 and $1 \%$ significance level respectively.

More specifically, Table 5 shows that at the $5 \%$ and $1 \%$ level of significance the maximum eigenvalue statistics and likelihood ratio (Trace Statistics) for the null hypothesis having no $(\mathrm{r}=0)$, co-integrations (24.23206 and 24.6414) is higher than the critical values at both the $5 \%$ and $1 \%$ level of significance. However, the maximum eigenvalue statistics and likelihood ratio (trace statistics) for the null hypothesis having one ( $\mathrm{r}=1)$, co-integrations ( 0.409314 for both) is lesser than the critical values at both the $5 \%$ and $1 \%$ level of significance. Hence, according to likelihood ratio and maximum eigenvalue statistics tests both the lnPCEC and lnPCGDP series are co-integrated. Thus, a long run equilibrium relationship between these series (lnPCEC and lnPCGDP) is co-integrated.

\section{Granger Causality Test}

The results of Granger causality between per capita lnPCEC, and per capita real lnPCGDP, computed $\chi^{2}$-values and their respective probabilities for the data of above mentioned series during the period 1980-2006 are presented in Table 6. To assess the null hypothesis, whether it is to be accepted or rejected, a significance level of $5 \%$ is chosen for causality test. The Granger causality test exhibits that the causality is running from per capita real GDP to per capita electricity consumption in Nepal not the other way.

\begin{tabular}{|c|c|c|c|}
\hline Regression & $X^{2}$-statistics & Probability & Implications \\
\hline $\begin{array}{c}\Delta \text { InPCEC on } \\
\triangle \text { InPCGDP }\end{array}$ & 3.9015 & 0.1422 & $\begin{array}{c}\text { InPCEC causing InPCGDP } \\
\text { (not significant at 5\% } \\
\text { level of significance) }\end{array}$ \\
\hline $\begin{array}{c}\Delta \text { InPCGDP on } \\
\Delta \text { InPCEC }\end{array}$ & 6.3931 & $0.0409^{*}$ & $\begin{array}{c}\text { InPCGDP causing InPCEC } \\
\text { (significant at 5\% level of } \\
\text { significance) }\end{array}$ \\
\hline
\end{tabular}

Table 6. Pairwise Granger Causality Test using VECM Model Based on Co-Integrated Regression

* Significance at 0.05 levels.

\section{Conclusion and Policy Implications}

Nepal possesses 42,00o MW of economic hydroelectricity potential, most of which remains largely untapped. A policy for increasing electricity supply investment is a prerequisite for enhancing economic growth in Nepal on the one hand,

\begin{tabular}{|c|c|c|c|c|c|c|c|}
\hline $\mathrm{H}_{0}$ & $\mathrm{H}_{1}$ & $\begin{array}{c}\text { Maximum eigen value } \\
\text { stat. }\end{array}$ & $\begin{array}{c}95 \% \text { Critical Value } \\
\text { (Eigen) }\end{array}$ & $\begin{array}{c}99 \% \text { Critical Value } \\
\text { (Eigen) }\end{array}$ & $\begin{array}{c}\text { Trace } \\
\text { Statistics }\end{array}$ & $\begin{array}{c}95 \% \text { Critical } \\
\text { Value (Trace) }\end{array}$ & $\begin{array}{c}99 \% \text { Critical } \\
\text { Value (Trace) }\end{array}$ \\
\hline $\mathrm{R}=0$ & $\mathrm{r}=1$ & 24.23206 & 11.44 & 15.69 & 24.6414 & 12.53 & 16.31 \\
\hline $\mathrm{R}=1$ & $\mathrm{r}=2$ & 0.409314 & 13.84 & 6.51 & 0.409314 & 3.84 & 6.51 \\
\hline
\end{tabular}

Table 5. Unrestricted Co-integration Rank Test

Notes: $\mathrm{H}_{0}$ and $\mathrm{H}_{1}$ denote the null and alternative hypothesis respectively. ' $r$ ' represents the number of co-integrating equations. 
while supplementing other forms of energy such as coal and oil through energy exchange programs in the neighbouring countries on the other. Estimates of electricity income and price elasticity from the time series data (1980-1999) have shown that the income elasticity of electricity was highly responsive. It shows that Nepal, for the long period of time does not have to arrange demand management. It further implies that more generation will create its own demand. It suggests that Nepal should accelerate more investment in generating hydroelectricity in order to improve supply management. This present study also suggests that Nepal will need to put more effort into increasing electricity supply investment as a national strategy towards advanced development in the long run.

The empirical findings of Granger causality test suggest that the causality is running from per capita real GDP to per capita electricity consumption in Nepal. It shows that it is the GDP that drives the energy consumption and not vice versa. The immediate implications of this study is that energy conservation will not hurt economic growth and development, though it is sometimes argued that energy conservation may adversely affect economic growth. Hence, energy conservation can be a feasible policy tool for Nepal because the country is severely constrained by adequate investment needed for exploiting hydro electricity potential. Given that electricity supply in Nepal is insufficient to meet the growing demand as reflected by the frequent load shedding, a well designed conservation policy can play effective role in managing the energy supply sector. It is suggested that the electricity utility sector should place its efforts to achieve energy efficiency by adopting different energy conservation measures that could limit energy related pollution and emissions. In addition, energy conservation measures make more energy available for economic activity and minimize economic losses incurred by the shortage of energy supply.

Kamal Raj Dhungel, $\mathrm{PhD}$, is Associate Professor in the Central Department of Economics, Tribhuvan University, Nepal. In addition, he has worked in the National Planning Commission of Nepal as a consultant and advisor. Dr. Dhungel has conducted various research works and has published several books and a number of articles in national and international journals, and has attended numerous national and international seminars.

Corresponding address: kamal.raj.dhungel@gmail.com

\section{References}

Aqeel, A. and M.S. Butt, 2001. 'The relationship between energy consumption and economic growth in Pakistan,' Asia Pacific Development J ournal 8(2):101-110.

Cheng, B.S. and Lai, T.W., 1997, 'An investigation of cointegration and causality between energy consumption and eonomic activity in Taiwan,' Energy Economics 19:435-444.

Dhungel, K.R., 2003, 'Income and price elasticity of the demand for energy: a macro-level empirical analysis,' Pacific and Asian J ournal of Energy 13(2):73-84.

Dhungel, K.R., 2005, 'Electricity demand in Nepal,' South Asian J ournal 10:127-138.

Dhungel, K.R., 2008, 'A causal relationship between energy consumption and economic growth in Nepal,' Asia-Pacific Development J ournal 15(1):137-150.

Ghali, K.H. and M.T. El-Sakka, 2004, Energy use and output growth in canada: a multivariate co-integration analysis,' Energy Economics 26:225-238.

Kraft, J. and A. Kraft, 1978, 'On the relationship between energy and GNP,' Journal of Energy Development 3:401403.

Mozumder, P and A Marathe, 'Causality relationship between electricity \& GDP in Bangladesh,' Energy Policy (www.unm. edu).

Mashih, A.M.M. and R. Mashih, 1996, 'Energy consumption real income and temporary causality results from a multicountry study based on cointegration and error correction modeling techniques,' Energy Economics 18:165-83.

Nepal NPC, 2003, The Tenth Plan, Kathmandu: National Planning Commission.

Pachauri, R.K., 1977, Energy and Economic Development in India, New York: Praeger.

Sims, C.A., 1972, 'Money, income and causality,' American Economic Review 62(4):540-552.

Soytas, U. and R. Sari, 2003, 'Energy consumption and GDP: Causality relationship in G-7 countries and emerging markets,' Energy Economics 25(1):33-37.

Stern, D.I., 2000, 'A multivariate cointegration analysis of the role of energy in the US macro economy,' Energy Economics 22(2):267-283.

Yang, H.Y., 2000, 'A note on the causal relationship between energy and GDP in Taiwan,' Energy Economics 22(3):309317. 